\title{
DURABILITY OF HDPE GEOMEMBRANES: AN OVERVIEW
}

\author{
Fernando Luiz Lavoiea,b,*,(1), Marcelo Kobelnik ${ }^{b}$, Clever Aparecido Valentin ${ }^{\mathrm{b}}$ and Jefferson Lins da Silva ${ }^{\mathrm{b}}$ \\ ${ }^{a}$ Departamento de Engenharia Civil, Instituto Mauá de Tecnologia, 09580-900 São Caetano do Sul - SP, Brasil \\ 'Departamento de Geotecnia, Escola de Engenharia de São Carlos, Universidade de São Paulo, 13560-970 São Carlos - SP, Brasil
}

Recebido em 02/12/2019; aceito em 23/03/2020; publicado na web em 04/05/2020

\begin{abstract}
The polymer demand for geotechnical applications has been growing. The geomembrane is a geosynthetic, manufactured, polymeric product and is often specified in environmental projects. Geomembranes started to be used in the 1930s but became more widespread in the 1940s. In the 1970s, geomembranes began to be specified for landfills. Over the past forty years, millions of square meters of HDPE geomembrane have been used in different applications. One of the most important issues for HDPE geomembranes is durability, involving very long-term property requirements. A rupture in the liner that has a geomembrane may provide losses in terms of human lives, environmental impacts, and financial costs. This paper summarizes the mechanisms and concepts involved in the HDPE geomembrane aging and describes the important contributions of laboratory and field studies over the years around the world. Different conditions and exposures drive the HDPE geomembrane behavior, including field temperature conditions and contact with different chemical substances. Accelerated laboratory testing with HDPE geomembrane simulating field boundary conditions is critical to ensure proper use of this geosynthetic in the future.
\end{abstract}

Keywords: geomembrane; HDPE; durability; aging.

\section{INTRODUCTION}

Geomembranes, or geosynthetics as barriers, are very low permeability coefficient polymeric sheets (typically $10^{-11} \mathrm{~cm} \mathrm{~s}^{-1}$ to $10^{-13} \mathrm{~cm} \mathrm{~s}^{-1}$ ), manufactured by the industry, delivered in rolls and installed in the site. They are often used in current landfill liners. Geomembranes can be produced with smooth faces or textured ones and with different colors. ${ }^{1-4}$

Geomembranes started to be used in the 1930 s, but became widespread in the 1940s. In the 1970s, geomembranes began to be specified for landfills. HDPE geomembranes started to be used first in Europe and South Africa, and then later on moved to North America. Initially, they were used in canals, and their applications then spread to Russia, Taiwan, Canada, and Europe. In the 1980s, HDPE geomembranes were famous for their high chemical resistance and for being thermally welded. The use of HDPE geomembranes in municipal landfills and the hazardous waste industry has advanced since 1985, mainly due to the high strength and low cost of the product. Nowadays, HDPE geomembranes are the most utilized component of the liner solutions in the world. ${ }^{1,5-8}$

Although quite subjective, current geomembrane application areas can be observed in three categories: transportation, environmental, and geotechnical. Each category has a number of specific applications which have been reported in the literature. ${ }^{1}$

Geomembranes are used in many situations and in different types of construction sites and structures, such as: ${ }^{9}$

- Solid waste landfills and industrial waste;

- Water ponds and waste liquid ponds;

- Waterproof liners with tunnels;

- Under highways;

- Farm ponds;

- Covers and subsoils of buildings;

- Raised or buried water tanks;

- Adduction and irrigation canals;

- Pools and artificial beaches;

*e-mail: fernando.lavoie@maua.br
- Vertical walls for contaminated areas.

Geomembranes are exposed to different aging mechanisms, including UV degradation, extraction degradation, thermal degradation, swelling, oxidative degradation, and biological degradation. These mechanisms can influence the material properties and even decrease their durability. ${ }^{10,11}$

High density polyethylene geomembranes are formulated with 96-97.5\% polyethylene, $2-3 \%$ UV protection, generally carbon black, and $0.5-1.0 \%$ antioxidants and thermostabilizers. ${ }^{12-16}$ This product exposed to aging can experience property changes due to molecular chain scission, crosslinking and bond breaking. ${ }^{12,17}$

The polymer polyethylene (PE) can be defined as polyolefin which has the hydrocarbon group containing carbon and hydrogen atoms in the chemical structure. When the co-monomer increases, the density of PE decreases. The density of polyethylene influences the physical and mechanical properties. There is a relationship between density and different PE properties, as shown in Figure 1. In general, the MDPE is more useful for liners, because it presents better chemical resistance, high strength, and low permeability when compared to LLDPE. However, HDPE, which is a semi-crystalline structure polymer, is susceptible to stress cracking. The HDPE geomembrane is formed by MDPE resin added with carbon black and additives, making the density greater than $0.940 \mathrm{~g} \mathrm{~mL}^{-1}$. $718-20$

Considering this, the objective of this paper is to present the mechanisms and concepts involved in the HDPE geomembrane

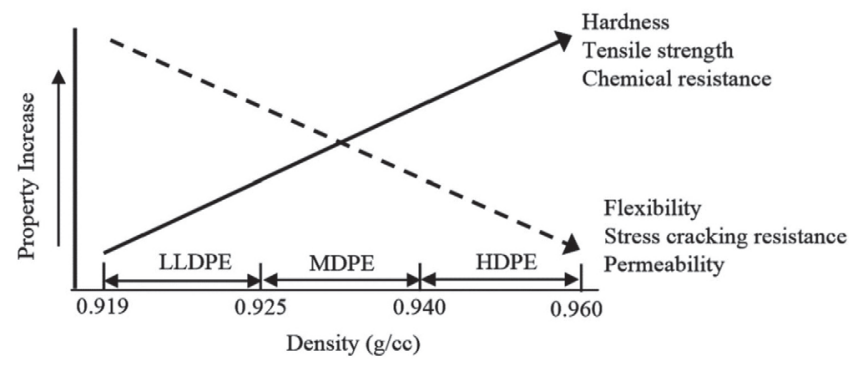

Figure 1. Material properties related to PE density ${ }^{18}$ 
aging and describe the important contributions of laboratory and field studies over the years around the world.

\section{TYPES OF DEGRADATION}

The main mechanisms of high-density polyethylene geomembrane degradation are ultraviolet degradation, thermal degradation, oxidative degradation and the synergic effects of these mechanisms occurring simultaneously.

\section{Oxidative degradation}

Polyolefins including polyethylene (PE) degrade by oxidation, in which there is a reaction between the polymer and the oxygen molecule. The whole process of oxidation in solid state polymers is so complex and heterogeneous that its nature and kinetics still raise many open questions. ${ }^{21}$

The main process for HDPE oxidation is a free radical chain mechanism. Figure 2 shows the oxidation mechanism involving twocycle processes. Cycle (A) is a chain reaction of alkyl/alkylperoxyl and the second one (B) is the formation of new radicals by chain reaction (homolysis of hydroperoxides). The oxidation can be stopped if all the links are foreclosed..$^{10,22,23}$

To prevent the oxidation of the polymers, antioxidants are included in the HDPE resin. Two different types of antioxidants are used: the primary and secondary. The good efficiency of antioxidants depends on the amount and types, and the field temperature. Primary antioxidants work to prevent free radical formation, while secondary antioxidants work to decrease the formation of active hydroperoxides in inactive alcohols..$^{24,25}$
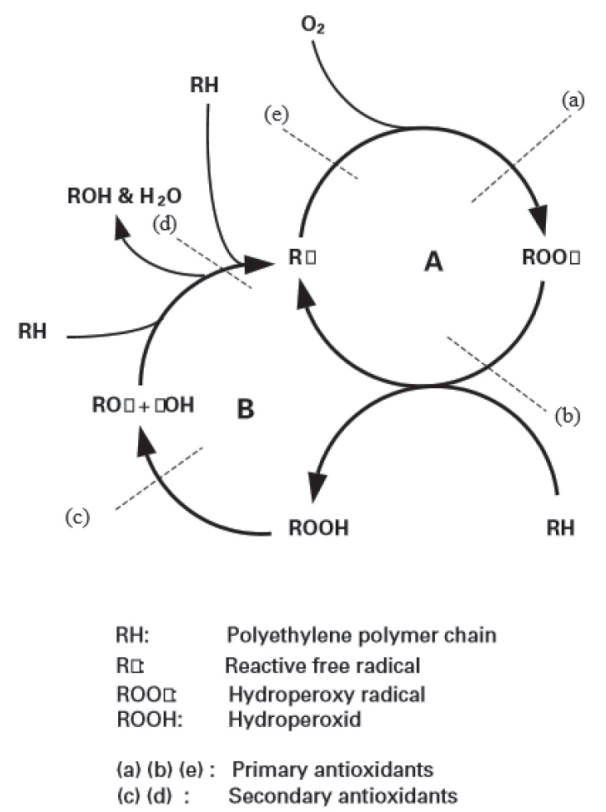

Figure 2. Oxidation cycle in polyethylene $e^{I 0}$

The oxidation of HDPE geomembranes can be evaluated through three different stages, which is shown in Figure 3. Stage (A), the first one, is relative to antioxidant depletion. The quantity of antioxidants is measured by the oxidative induction time (OIT) test. In the second stage (B), the chain reaction begins, and changes in the molecular composition start. The third stage (C) represents significant changes in the molecular composition with the formation of free radicals, and cross-linking occurs in the free radicals. The result of these changes is a totally changed molecular structure, decreased in strength properties, the appearance of cracks, and there is an increase in the stress cracking susceptibility, culminating at the end of service-life. ${ }^{10,17,26-30}$

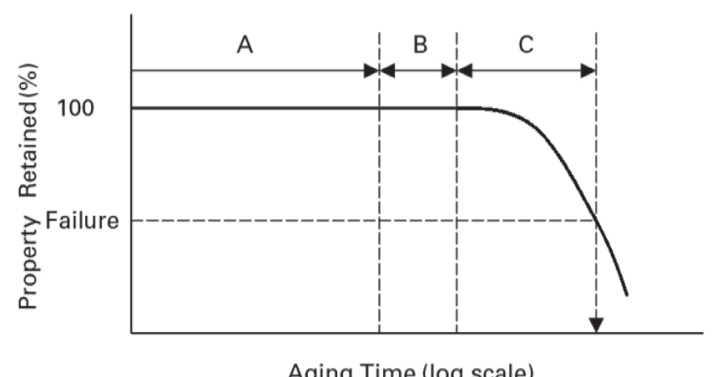

$A=$ Period during which depletion of antioxidants occurs

$\mathrm{B}=$ Induction time to onset of polymer degradation

$\mathrm{C}=$ Time to reach the failure level of degradation of a particular property

Figure 3. The concept of HDPE geomembrane oxidative degradation ${ }^{10}$

High-density polyethylene geomembranes have several different degradation mechanisms, but, for base liner applications, oxidative degradation can be considered the most harmful. ${ }^{12,30}$

\section{Photo-degradation}

The lifetime of geomembranes is led by ultraviolet radiation (UV), or a combination of thermal and UV exposure. For this reason, carbon black is added to the blend to protect the HDPE, normally $2 \%$ to $3 \%$. $^{1,31-34}$

The black geomembrane surface temperature, which was installed uncovered and exposed to solar radiation, reached over $70{ }^{\circ} \mathrm{C} . .^{35}$

The sun's radiation wavelength prolongs from the infrared, through the visible spectrum into the ultraviolet. The infrared is bigger than $700 \mathrm{~nm}$, the visible spectrum is between $400-700 \mathrm{~nm}$ and ultraviolet radiation is at $400 \mathrm{~nm}$. Polymer chain scission and degradation of polymer properties can occur when the UV radiation reaches the geomembrane surface. ${ }^{36}$

In exposed geomembrane applications, polyethylene (PE) is in contact with UV radiation, and the degradation is led by photooxidation with several free radical reactions (Expression 1). ${ }^{36,37}$

$$
\mathrm{RH}+\mathrm{O}_{2}+\mathrm{h} v \Rightarrow \mathrm{R} \bullet+\mathrm{ROO} \bullet+\mathrm{RO} \bullet+\mathrm{OH} \bullet
$$

The $\mathrm{R} \bullet, \mathrm{ROO} \bullet, \mathrm{RO} \bullet$ and $\mathrm{OH} \bullet$ are the free radicals, $\mathrm{RH}$ is the polymer chain, $\mathrm{h} v$ is the photon energy with $\mathrm{h}$ and $v$ representing Planck's constant and wavelength. ${ }^{36}$

There are different methods to study the behavior of plastics facing UV radiation. The natural solar radiation is used to evaluate sunlight degradation, but it requires a long-term evaluation. Laboratory methods to evaluate the UV radiation are weatherometers, such as xenon-arc and ultraviolet-fluorescent. The correlation between sunlight exposure and weatherometers is controversial because there are several factors involving both types of exposure. ${ }^{36}$

\section{Thermal degradation}

A geomembrane may be submitted to higher temperatures than normal prior to installation, during installation, and during service. Thermoplastic geomembranes, if exposed to heat such as rolled or folded panels prior to installation, such as left in the sun, can block or stick together; afterward, when unfolded, a coated geomembrane may split, or an unreinforced geomembrane may tear and become unserviceable. ${ }^{1}$ 
High temperatures can hasten UV and oxidative degradations, causing changes in physical, chemical and mechanical properties. In HDPE geomembranes, temperatures in the range of 80 to $90{ }^{\circ} \mathrm{C}$ are suggested as the maximum. Temperatures around $105^{\circ} \mathrm{C}$ or higher should be avoided because the melting point of polyethylene is $125^{\circ} \mathrm{C} . .^{6,33,38,39}$

Many authors reported field temperatures for HDPE geomembranes. In a landfill liner, the temperature might reach $80^{\circ} \mathrm{C}$ to $90^{\circ} \mathrm{C}$. For nickel heap leach pads, the liner temperature may reach $70{ }^{\circ} \mathrm{C}$. Some leachate temperatures above $143{ }^{\circ} \mathrm{C}$ are reported in a landfill with aluminum industry waste. ${ }^{40,41}$

The DSC (differential scanning calorimetry) analysis can show the changes in polymer morphology through high temperatures, such as annealing and chemical degradation. The peak associated with the recrystallization of the molten material after cooling to ambient temperature, even the peak associated with recrystallization of the molten material during annealing and the endothermic peak representing the melting can be seen by the DSC thermogram. ${ }^{40}$ The DSC thermogram presents three peaks. Peak 1 represents the recrystallisation of the molten material upon cooling to ambient temperature. Peak 2 represents the peak associated with recrystallisation of the molten material during annealing. Peak 3 represents the endotherm peak of the melting of most of the lamella at temperature $\mathrm{T}_{3}{ }^{39}$

\section{Chemical degradation}

When in service, geomembranes are subjected to various chemical attacks. The general chemical resistance of different geomembranes to well defined chemicals is usually known. The problem arises when the chemical is not a single component material: in this case, possible synergistic effects, that are not completely known, can be originated. ${ }^{1}$

It is important to observe what kind of chemical substances are directly in contact with a geomembrane in a design. Manufacturers need to evaluate the chemical resistance of geomembranes because the good behavior of geomembranes must be guaranteed at least during the useful life. ${ }^{6}$

A structure modification of high-density polyethylene caused by chemical aging can culminate in chain scission or cross-linking. The chain scission reduces the molecular weight of the polymer, influencing the mechanical properties and the material becomes brittle. The cross-linking changes the mechanical behavior, increasing the stiffness. ${ }^{11}$

\section{ENVIRONMENTAL STRESS CRACKING}

Stress cracking of polymers is a phenomenon caused by tensile stresses less than mechanical strength which promotes internal or external cracks. These cracks should be accelerated by the environment. The stress cracking resistance of HDPE geomembranes is of great interest because the high crystallinity of HDPE puts the occurrence of this phenomenon at risk. The notched constant load (NCTL) test assesses the stress cracking resistance of HDPE geomembranes using a dogbone specimen that is notched in its central region with $20 \%$ of the total thickness. Different percentages of tensile load are applied while being immersed in a solution with $10 \%$ of Igepal CO-630 (surfactant) and $90 \%$ of water at $50{ }^{\circ} \mathrm{C} \cdot .^{12,41-46}$

The melt flow index test (MFI) can provide a parameter on stress cracking. An HDPE geomembrane with a low melt flow index exhibits good stress cracking environmental resistance (less than $1.0 \mathrm{~g} / 10 \mathrm{~min}$ $\left(190{ }^{\circ} \mathrm{C}-2.16 \mathrm{~kg}\right.$ ). Any change in the MFI should be related to the degradation of the geomembrane..$^{41,47}$

The NCTL test can provide the transition time of the geomembranes because the failure times of the test specimens at various stresses are recorded and then plotted. The transition point between the two differently sloped portions is called transition time $T_{t}$ and represents the transition from ductile behavior to brittle behavior of the polymer. The response of the curves resulting can be a "knee" (bi-linear curve), "nose" (overshoot curve) and "step" (tri-linear curve). A geomembrane which provides a high $\mathrm{T}_{\mathrm{t}}$ value will exhibit a better stress cracking resistance than one with a lower $T_{t}$ value. ${ }^{47}$

The first occurrences reported about stress cracks in geomembranes were observed along the seams.

There have been several field reported incidents of stress cracking. All have been on polyethylene geomembranes exposed to the environment. Thus, ultraviolet light and oxidation are involved, as well as expansion and contraction to the extent that the geomembrane surface varies in temperature. All of the cracks occurred, or at least started, at field seams, according to different authors. In 1981 in the southwest of the US, a $2.0 \mathrm{~mm}$ thick HDPE geomembrane in contact with sludge for 7 years presented severity cracks along the seams caused by thermal stress. In 1989 in Canada, a $2.0 \mathrm{~mm}$ thick HDPE geomembrane in contact with black liquor with 2 years of service presented a large cracked area spreading throughout sheets and seams. In 1989 in Italy, a $2.0 \mathrm{~mm}$ thick HDPE geomembrane for the cover liner with 4 years of service presented small cracks at the seams and long cracks in the sheet. ${ }^{1,48,49}$

\section{SERVICE LIFE PREDICTION OF HDPE GEOMEMBRANES}

Long-term performance of HDPE geomembranes depends on several aspects, such as field temperature, exposure conditions, field stresses, covered or protected conditions, kind of liner layers, and resin and additive formulations. The service life of geomembranes can be predicted based on accelerated tests in the laboratory using Arrhenius modeling, which makes a time-temperature prediction and can be estimated from a few years to 1000 years. ${ }^{10,50-53}$

Several authors have used oxidative induction time (OIT) and Arrhenius modeling to estimate the service life of HDPE geomembranes through the antioxidant's depletion. The OIT value is an index parameter related to the amount of antioxidant in the sample and is very useful for monitoring the antioxidant depletion in the HDPE geomembranes. The OIT value of the GM decreases as antioxidants are depleted with time. ${ }^{10,54-56}$ The determination of the OIT value from a standard test is shown in Figure 4.

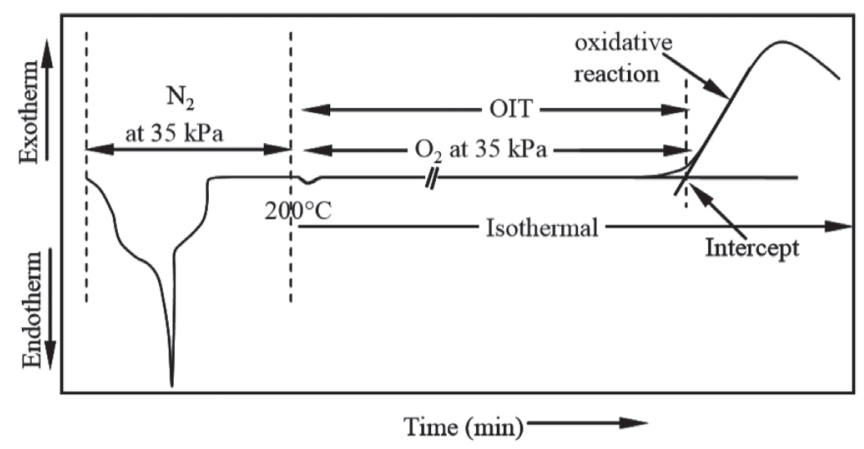

Figure 4. DSC thermogram from a standard OIT test ${ }^{18}$

Jessberger and Heibrock ${ }^{57}$ estimated the service life of an HDPE geomembrane to be over 300 years under constant oxygen supply and $20{ }^{\circ} \mathrm{C}$, but at $40{ }^{\circ} \mathrm{C}$, under the same conditions, the service life was estimated to be approximately 45 years. Koerner ${ }^{10}$ estimated the service life of the backfilled HDPE geomembrane at 550 years under $20{ }^{\circ} \mathrm{C}$, but at $40{ }^{\circ} \mathrm{C}$ the estimated service life was 90 years. ${ }^{10,23,54,55}$ 
According to Rowe and Ewais, ${ }^{16}$ there is a need for more data related to the properties of geomembranes in the field after their useful life.

\section{STUDIES OF HDPE GEOMEMBRANE DURABILITY}

Many studies on HDPE geomembranes have been conducted in different parts of the world for over thirty years. Laboratory tests were carried out using virgin samples to simulate the field conditions. Exhumed samples of HDPE geomembranes were tested in the laboratory to understand the behavior of geomembranes after real expositions. Finally, field studies were performed to verify the service boundary conditions of the geomembranes.

\section{Laboratory studies of HDPE geomembrane durability}

Mitchell ${ }^{58}$ studied two compatibility tests with synthetic leachate from a uranium mill, one of them with a two-sided exposure sample and another one simulating a uranium tailing pond with a one-side exposure sample. The tests were conducted through columns at 18 , 47 , and $76{ }^{\circ} \mathrm{C}$ using a $1.0 \mathrm{~mm}$ thick high-density geomembrane. Moreover, destructive tests were performed after 1, 7, 30 and 120 days. The differential infrared transmission analysis results did not show oxidation products in the aged material. Changes in crystallinity were noted by differential scanning calorimetry (DSC). The virgin sample crystallinity was $52.3 \%$, while crystallinity for exposed samples at 18,47 and $76{ }^{\circ} \mathrm{C}$ was $51.5,53.4$ and $55.7 \%$, respectively.

Schoenbeck ${ }^{59}$ tested seam samples with several methods to seam chlorosulfonated polyethylene (CSPE) geomembranes, such as dielectric seaming factory seams, by hot air and with a bodied solvent as well as a field seam made with a bodied solvent. The xenon arc weatherometer was used to conduct aging tests in hot air at $63{ }^{\circ} \mathrm{C}$ and $100{ }^{\circ} \mathrm{C}$. Test results showed a significant increase in shear strength after 3000 hours.

Dix and Burkinshaw ${ }^{60}$ conducted differential scanning calorimeter and melt flow index tests to evaluate the density of HDPE resins. The results showed that there is a tendency for density to decrease in lower heat of fusion and lower melting points.

Hsuan and Koerner ${ }^{12}$ conducted acceleration stress cracking tests for HDPE geomembrane 1 at $75^{\circ} \mathrm{C}$ and slow stress cracking tests for HDPE geomembrane 2 at $40^{\circ} \mathrm{C}$ and $25^{\circ} \mathrm{C}$. The acceleration test is used for high-stress cracking resistance geomembrane and slow stress cracking test for low stress cracking resistance geomembrane. The results showed transition time values of 600 hours at $50{ }^{\circ} \mathrm{C}$ and 40 hours at $75^{\circ} \mathrm{C}$ for HDPE geomembrane 1 , and 6 hours at $50{ }^{\circ} \mathrm{C}$, 12 hours at $40^{\circ} \mathrm{C}$, and 70 hours at $25^{\circ} \mathrm{C}$ for HDPE geomembrane 2 . It is not recommended to use temperatures higher than $85^{\circ} \mathrm{C}$ for HDPE as they cause material property changes.

Different organic liquids were used to evaluate the chemical compatibility with a $1.5 \mathrm{~mm}$ thick HDPE geomembrane by Aminabhavi and $\mathrm{Naik}^{61}$ at 25,50 and $70{ }^{\circ} \mathrm{C}$, including acetone, benzene, toluene, 1-chloronaphthalene, methyl ethyl ketone, methyl iso-butyl ketone, cyclohexanone, butyraldehyde, and others. The results showed that the sample has a high resistivity to these liquids and the diffusive transport of liquids depends on the temperature and concentration.

Results from a laboratory exposure program were presented by Gulec et al. ${ }^{56}$ using a $1.5 \mathrm{~mm}$ HDPE geomembrane in contact with acidic mine drainage that came from a metallic mine waste facility. They used synthetic acidic mine drainage, acidic water, and deionized water at 20,40 , and $60{ }^{\circ} \mathrm{C}$ for a 22-month period. Results of the melt flow index (MFI) test, Fourier transform infrared spectroscopy (FTIR), and oxidative induction time (OIT) demonstrated that MFI seems to increase gradually, the antioxidant depletion time was approximately from 46 to 426 years. It should be mentioned that no changes were observed in the polymer structure.

Merry et al. ${ }^{62}$ used an axisymmetric tension test apparatus that can perform constant-stress creep tests to compare the creep response of new and old HDPE geomembranes. Thirty-six-hour constant-stress creep tests were performed on new (about one year old) HDPE using a temperature range of $2-53{ }^{\circ} \mathrm{C}$ and stresses ranging from 2 to $15 \mathrm{MPa}$. Excess material was then stored in a laboratory for an additional 7 years, after which time tests on old geomembranes were performed. The results showed that there was essentially no difference in the creep response of the old geomembranes (7 year-stored sample).

The study of the thickness influence on antioxidant depletion from nominal 1.5, 2.0, and 2.5 mm HDPE geomembranes was conducted by Islam and Rowe. ${ }^{63}$ They immersed the samples in synthetic leachate at four temperatures $\left(22,55,70\right.$, and $\left.85^{\circ} \mathrm{C}\right)$ and the standard oxidative induction time test was used to evaluate the behavior of different thicknesses. The results showed that antioxidants depleted faster from the $1.5 \mathrm{~mm}$ sample than others. According to the authors, thicker geomembranes have longer service lives.

Rowe et al..$^{64}$ tested a $1.5 \mathrm{~mm}$ thick high-density geomembrane on different laboratory leachates at $85^{\circ} \mathrm{C}, 70{ }^{\circ} \mathrm{C}, 55^{\circ} \mathrm{C}, 40^{\circ} \mathrm{C}$, and $22{ }^{\circ} \mathrm{C}$. They used Arrhenius modeling to evaluate the depletion of antioxidants. The results showed that faster depletion occurred in acidic and basic leachates and the $\mathrm{pH}$ varied from 4 to 10 .

The results of the 28,000 hour-test of the laboratory weatherometer was presented by Koerner et al. ${ }^{65}$ The authors used HDPE and LLDPE geomembranes $1.5 \mathrm{~mm}$ thick, and $1.0 \mathrm{~mm}$ thick, respectively. The test results showed both samples starting the degradation mechanisms due to the losses in tensile properties verified. The LLDPE sample showed more degradation than the HDPE sample. According to the authors, the geomembrane lifetime depends on exposure site conditions.

Rimal and Rowe ${ }^{54}$ studied the behavior of HDPE geomembranes called "conventional or untreated" and fluorinated HDPE geomembranes or f-HDPE using fluorine gas (F2) to create a barrier to hydrocarbons. They immersed the HDPE and f-HDPE geomembranes in Jet A-1 at $23{ }^{\circ} \mathrm{C}$ and, later, they compared them at 23,9 and $-22{ }^{\circ} \mathrm{C}$ and used $1.5 \mathrm{~mm}$ thick HDPE, $1.5 \mathrm{~mm}$ thick f-HDPE and $2.0 \mathrm{~mm}$ thick HDPE. The samples can be differentiated by Fourier transform infrared (FTIR) scans. The authors measured the crystallinity of the samples, and no changes were observed. The antioxidant depletion study showed that f-HDPE had 30\% more than the conventional HDPE.

The tensile properties in these samples were measured by the authors. It was observed that there is a statistically significant difference in tensile yield properties between the 'dry' and 'wet' test conditions. Higher yield strain was obtained in the 'wet' condition due to the softening effect of the jet fuel absorbed in the samples. On the other hand, the yield strength of the samples was lower in the 'wet' condition. The tensile break results did not show a statistically significant difference. ${ }^{54}$

Rowe et al. ${ }^{66}$ tested a $2.0 \mathrm{~mm}$ thick high-density geomembrane exposed to water, leachate and air for 8 to 10 years. Several tests were conducted, such as OIT, crystallinity, tensile strength, stress cracking, melt flow index and surface analysis. The results showed that the service life, according to Arrhenius modeling, can reach more than 700 years immersed in leachate at $20^{\circ} \mathrm{C}$, it can reach about 300 years at $35^{\circ} \mathrm{C}$, and more than 50 years at $50{ }^{\circ} \mathrm{C}$.

The temperature of the secondary geomembrane used in the landfill liners was estimated by Rowe and Hoor. ${ }^{67}$ According to the authors, the liner thickness and configuration can affect the temperature. The temperature predictions showed which service life of the secondary geomembrane can reach 390 years at $50{ }^{\circ} \mathrm{C}$ and 75 years 
at $50{ }^{\circ} \mathrm{C}$ if the liner has a primary liner comprising the geomembrane, a geosynthetic clay liner and at least $1 \mathrm{~m}$ of the foundation layer.

Lodi and Bueno ${ }^{13}$ tested HDPE virgin and exposed (leachate and weathering for 30 months) geomembrane samples ( 0.8 and $2.5 \mathrm{~mm}$ of thickness). They utilized a thermogravimetric (TG) analysis to understand the behavior of the samples. Table 1 shows the values of the mass loss after TG tests. Figures 5 and 6 show the results of these analyses. It can be observed that for the $0.8 \mathrm{~mm}$ virgin sample, the initial mass loss temperature was $420^{\circ} \mathrm{C}$, while this value was $440{ }^{\circ} \mathrm{C}$ to $480{ }^{\circ} \mathrm{C}$ for the exposed samples. For HDPE polymers, it is supposed that the mass loss starts at $470{ }^{\circ} \mathrm{C}$. For $2.5 \mathrm{~mm}$ thick samples, this behavior is the same as $0.8 \mathrm{~mm}$ thick samples, and the values with the initial temperature mass loss were close.

Table 1. Values of the mass loss after TG tests ${ }^{13}$

\begin{tabular}{lccc}
\hline Condition & HDPE $(\mathrm{mm})$ & Parameter A $(\%)$ & Parameter B (\%) \\
\hline Fresh & 0.8 & 99.79 & 0.15 \\
& 2.5 & 99.41 & 0.17 \\
\hline Weathering & 0.8 & 99.90 & 0.08 \\
& 2.5 & 98.30 & 1.12 \\
\hline Leachate & 0.8 & 99.11 & 0.10 \\
& 2.5 & 97.91 & 1.72 \\
\hline
\end{tabular}

$\mathrm{A}=$ Polymer; $\mathrm{B}=$ Residual mass (carbon black + ash).

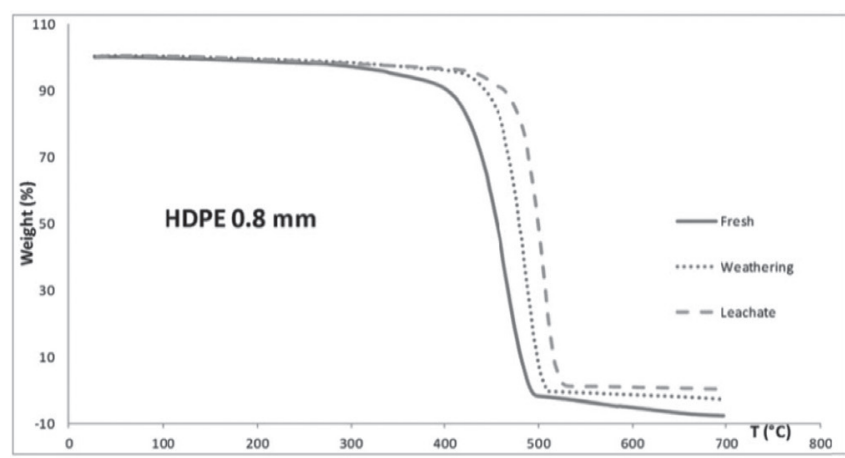

Figure 5. TG curves of $0.8 \mathrm{~mm}$ HDPE geomembrane sample ${ }^{13}$

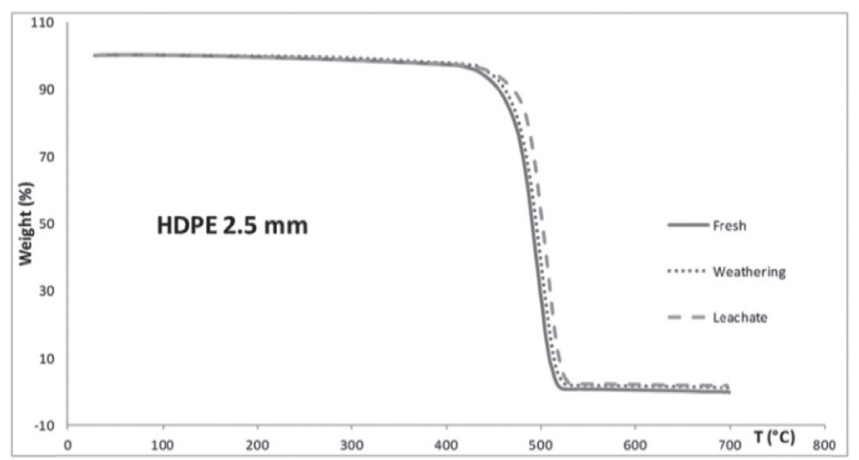

Figure 6. TG curves of $2.5 \mathrm{~mm}$ HDPE geomembrane sample ${ }^{13}$

Lavoie et $a l .{ }^{68}$ studied the stress cracking behavior of a highdensity polyethylene geomembrane $(2.0 \mathrm{~mm}$ thick). They tested the virgin sample by the notched constant tensile load test (NCTL) and the exposed samples by ultraviolet radiation (weatherometer) for 480 hours, thermal aging at $85^{\circ} \mathrm{C}$ (air oven) for 2,106 hours, immersed in a solution with $10 \%$ in mass of sodium hydroxide at $50{ }^{\circ} \mathrm{C}$ for 2,880 hours. The authors commented that the exposed agents can accelerate the process of stress cracking because the exposed samples had a $50 \%$ to $60 \%$ of the decrease in the stress cracking resistance. Figure 7 presents the resulting curves of the applied versus respective failure times.

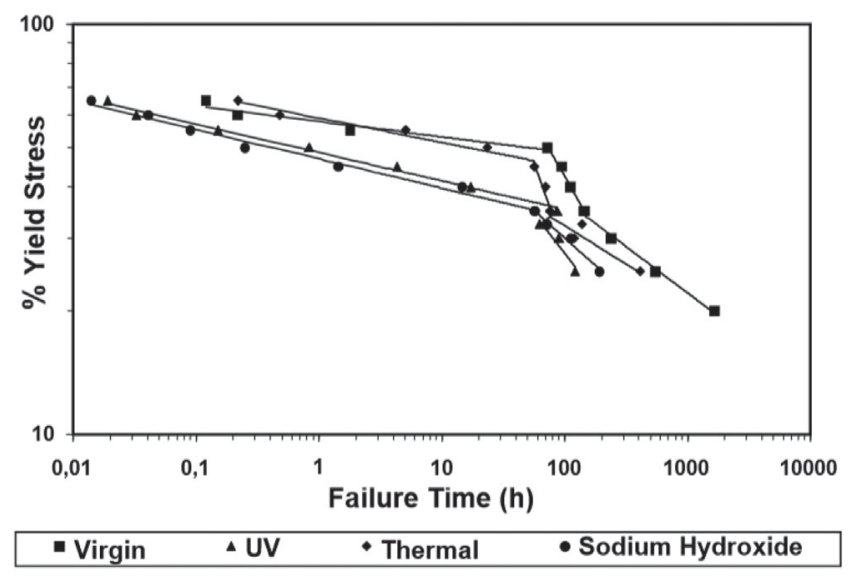

Figure 7. NCTL test curves ${ }^{68}$

A study provided by Abdelaal et al. ${ }^{69}$ evaluated the behavior of $1.5 \mathrm{~mm}$ thick HDPE and LLDPE geomembranes in acidic solutions with $\mathrm{pH}=0.5$ at 40,50 , and $60{ }^{\circ} \mathrm{C}$ that represents the mining solutions for nickel, uranium, and copper heap leaching well with $\mathrm{pH}$ between 0.5 to 2.0. The research showed which depletion of the antioxidants for HDPE was faster than LLDPE resulting in 28 and 29 years at $40{ }^{\circ} \mathrm{C}, 16$ and 17 years at $50{ }^{\circ} \mathrm{C}$, and 9 and 11 years at $60^{\circ} \mathrm{C}$, respectively for HDPE and LLDPE samples.

Lodi et al. ${ }^{70}$ evaluated the chemical compatibility of high-density polyethylene geomembranes with different thicknesses, 0.8 and $2.5 \mathrm{~mm}$. The authors immersed the samples in a leachate and $60 \%$ niobium solution for a maximum of 120 days at 23 and $50{ }^{\circ} \mathrm{C}$. Both samples presented an increase in tensile elongation. The results of melt flow index tests showed a significant increase in the $2.5 \mathrm{~mm}$ sample, $52.7 \%$ for niobium and $75.2 \%$ for leachate. These increases indicate the chain scission mechanism.

Vinasse, an acid leachate from sugarcane, is commonly stored in HDPE geomembrane lined tanks. On the other hand, sodium hydroxide is widely used in the bauxite purification process and HDPE geomembrane is used as a pond liner. Lavoie et al. ${ }^{71}$ studied the chemical compatibility of a $2.0 \mathrm{~mm}$ HDPE geomembrane at $50{ }^{\circ} \mathrm{C}$ for 120 days in a vinasse solution (acid solution) and also in a $10 \%$ mass solution of sodium hydroxide (alkaline solution). The results of these immersions showed that thermogravimetric analysis did not show changes in thermal stabilities, but an average decrease was noted in the tensile yield strength of $34 \%$ for the vinasse sample and an expressive tear strength loss of $40 \%$ was verified in the sodium hydroxide sample.

Buaszczyk $^{72}$ evaluated the effects of HDPE geomembranes (1.0 and $2.0 \mathrm{~mm}$ of thickness) immersed in hot and warm vinasse for 245 days, through physical, mechanical and thermal properties. Analyses by scanning electron microscopy (SEM) for the virgin $1.0 \mathrm{~mm}$ sample and 153 days of hot and warm exposition $1.0 \mathrm{~mm}$ sample were performed. It can be observed that both immersed samples presented flatter relief probably due to the effect of abrasion. Using Arrhenius modeling, the depletion of antioxidants was estimated in 4.3 years for the $1.0 \mathrm{~mm}$ thick geomembrane and 5 years for the $2.0 \mathrm{~mm}$ thick geomembrane. After 153 days of hot and warm exposition, thermo-oxidative degradation was observed preferably by branching into low molar mass fractions.

Abdelaal and Rowe ${ }^{73}$ evaluated a high-density polyethylene geomembrane with $1.5 \mathrm{~mm}$ of thickness without the presence of 
hindered amine light stabilizers (HALS) in the composition of the product, immersed in chlorinated water at different temperatures. The results showed that by using the Arrhenius modeling, the depletion of antioxidants varied from 0.5 to 23 years, respectively, at $20{ }^{\circ} \mathrm{C}$ and $60{ }^{\circ} \mathrm{C}$.

HDPE geomembranes under high temperatures were evaluated by Abdelaal and Rowe. ${ }^{74}$ Four samples of different geomembranes were incubated in leachate, water, and air at 95,105 and $115^{\circ} \mathrm{C}$. According to the authors, incubation in air at $115^{\circ} \mathrm{C}$ caused polymer degradation. High temperatures above $95{ }^{\circ} \mathrm{C}$ should be used with caution. The degradation of geomembranes may occur before the complete depletion of antioxidants.

The accelerated notched tensile constant load test (NCTL) was evaluated by Lavoie et al. ${ }^{46}$ using a $2.0 \mathrm{~mm}$ thick high-density polyethylene geomembrane at $70{ }^{\circ} \mathrm{C}$ and $50{ }^{\circ} \mathrm{C}$ as a reference. The transition time by accelerated test $\left(\mathrm{T}_{\mathrm{t}}=18\right.$ hours $)$ decreased $87 \%$ compared to the reference test $\left(\mathrm{T}_{t}=143\right.$ hours $)$. According to the authors, the behavior between both tests is different. The accelerated test provided a bi-linear curve, while the reference test provided a tri-linear curve.

The research conducted by Rowe et al. ${ }^{66}$ for 2.65 years was continued by Abdelaal et al..$^{75}$ for another 6.5 years. In summary, the results showed that the salts contained in leachates 1 and 3 changed the stress cracking resistance, and even the mechanical properties of the sample.

Ewais et al. ${ }^{14}$ examined HDPE geomembranes, $1.5 \mathrm{~mm}$ thick, and manufactured them with different resins and additives. They immersed the samples in an artificial landfill leachate at $85{ }^{\circ} \mathrm{C}$ and used the high-pressure oxidative induction time (HP-OIT) to evaluate the behavior of the samples. The largest HP-OIT was 960 minutes suggesting the presence of hindered amine light stabilizers (HALS) in the additive package, because traces of nitrogen were found. The lowest HP-OIT was 260 minutes and no traces of nitrogen were detected, which suggests no presence of HALS.

Four different high-density polyethylene geomembranes, $1.5 \mathrm{~mm}$ thick, incubated in air at high temperatures were evaluated by Abdelaal et al. ${ }^{39}$ These aging samples were investigated by oxidative induction time tests (standard and high-pressure), the melt flow index test, the stress cracking test (single point), and the morphological changes due to annealing, using the differential scanning calorimetry (DSC). The results of DSC curves for sample GMB1 aged at 115 and $105^{\circ} \mathrm{C}$ showed changes in melt behavior of aged samples by the increase of the temperatures' incubation. The melting point was $127^{\circ} \mathrm{C}$ for virgin samples and increased to $131.6^{\circ} \mathrm{C}$ for 4.2 months of incubation. For times higher than 4.2 months, the melting point increased to $140{ }^{\circ} \mathrm{C}$.

Aged samples experienced losses in stress cracking resistance and flow index, showing changes in polymer morphology. It was observed, especially at high temperatures, that both mechanisms of degradation (cross-linking and chain scission) occurred at the same time. ${ }^{39}$
Finally, the authors concluded that morphological changes associated with annealing occurred for samples incubated in air at temperatures higher than $85^{\circ} \mathrm{C}$, and the samples had different thermal behaviors due to high temperatures. ${ }^{39}$

Morsy and Rowe $\mathrm{e}^{76}$ evaluated the depletion of antioxidants from different geomembranes immersed in chlorinated water at $85{ }^{\circ} \mathrm{C}$. Chlorine is a strong agent of oxidation. The geomembranes tested were $1.5 \mathrm{~mm}$ thick, two from HDPE and one from LLDPE. After 20 days of exposure, the HDPE samples presented higher rates of antioxidant depletion than LLDPE samples. According to the authors, while a high initial Std-OIT is usually preferred, the type of antioxidant and thus its resistance to chlorinated water may govern the time to antioxidant depletion.

Ewais et.${ }^{77}$ evaluated the rupture time to an HDPE geomembrane (1.5 mm of thickness) under $250 \mathrm{kPa}$ of pressure, at $85{ }^{\circ} \mathrm{C}$ in a composite liner configuration in 0.6-m-diameter geosynthetic liner longevity simulator cells. The tests were performed not replacing the gravel and replacing the gravel and using a nonwoven geotextile as a protective layer. The differences in the times to rupture in these different scenarios were attributed to the observed deterioration of the gravel above the geomembrane. For the conditions examined in the study with a geotextile as a protection layer, the gravel deterioration observed in this study was important in terms of protecting the geomembranes from rupturing. The authors concluded that the physically/chemically induced deterioration of the gravel can prolong the time HDPE geomembranes would take to rupture. The increase in the time to rupture would depend on the degree of the gravel deterioration.

Several polymers of polyethylene have been studied by Muñoz Gómez ${ }^{47}$ concerning crystallinity, melt flow index and stress cracking resistance. According to the author, each of the polymers analyzed was transformed into a polyethylene sheet following this general formulation with a base polymer, carbon black, antioxidants and ultraviolet stabilizers. Manufacturing was completed by a flatdie cast co-extrusion system. In all cases, the geomembrane was $7.5 \mathrm{~m}$ wide and $1.5 \mathrm{~mm}$ thick. The stress cracking resistance values were improved for higher densities but wider weight distribution. Samples with narrow molecular weight, but with lower density could improve their stress cracking resistance. The best situation was noted for a low-density sample with wider molecular weight distribution. Density, crystallinity, and melt flow index results are shown in Table 2.

The estimated half-life of an HDPE geomembrane with $1.5 \mathrm{~mm}$ of thickness in the covered or nonexposed condition was determined by Koerner et al $^{78}$ They incubated the sample in a device simulating a liner situated under $50 \mathrm{~m}$ of solid waste at $55,65,75$ and $85^{\circ} \mathrm{C}$ and determined the half-life when the values of strength or elongation reached $50 \%$. The extrapolation of half-life made for $20{ }^{\circ} \mathrm{C}$ resulted in about 450 years.

Table 2. Density, crystallinity, and melt flow index (MFI) of the polymers used ${ }^{47}$

\begin{tabular}{|c|c|c|c|c|c|}
\hline Polymer & Density $\left(\mathrm{g} / \mathrm{cm}^{3}\right)$ & Crystallinity (\%) & $\begin{array}{c}\text { MFI g/10 min } \\
\left(190^{\circ} \mathrm{C} / 2.16 \mathrm{~kg}\right)\end{array}$ & $\begin{array}{c}\text { MFI g/10 min } \\
\left(190^{\circ} \mathrm{C} / 5.0 \mathrm{~kg}\right)\end{array}$ & $\begin{array}{c}\text { MFI g/10 min } \\
\left(190^{\circ} \mathrm{C} / 21.6 \mathrm{~kg}\right)\end{array}$ \\
\hline PE-1 & 0.932 & 51.2 & 0.78 & 2.19 & 19.76 \\
\hline PE-2 & 0.934 & 49.9 & 0.15 & 0.63 & 16.59 \\
\hline PE-3 & 0.936 & 56.8 & 0.93 & 2.65 & 23.54 \\
\hline PE-4 & 0.937 & 53.4 & 0.23 & 0.95 & 19.84 \\
\hline PE-5 & 0.938 & 54.5 & 0.23 & 1.0 & 18.95 \\
\hline PE-6 & 0.940 & 59.0 & 0.95 & 2.78 & 25.92 \\
\hline PE-7 & 0.941 & 49.4 & 0.12 & 0.57 & 11.67 \\
\hline
\end{tabular}



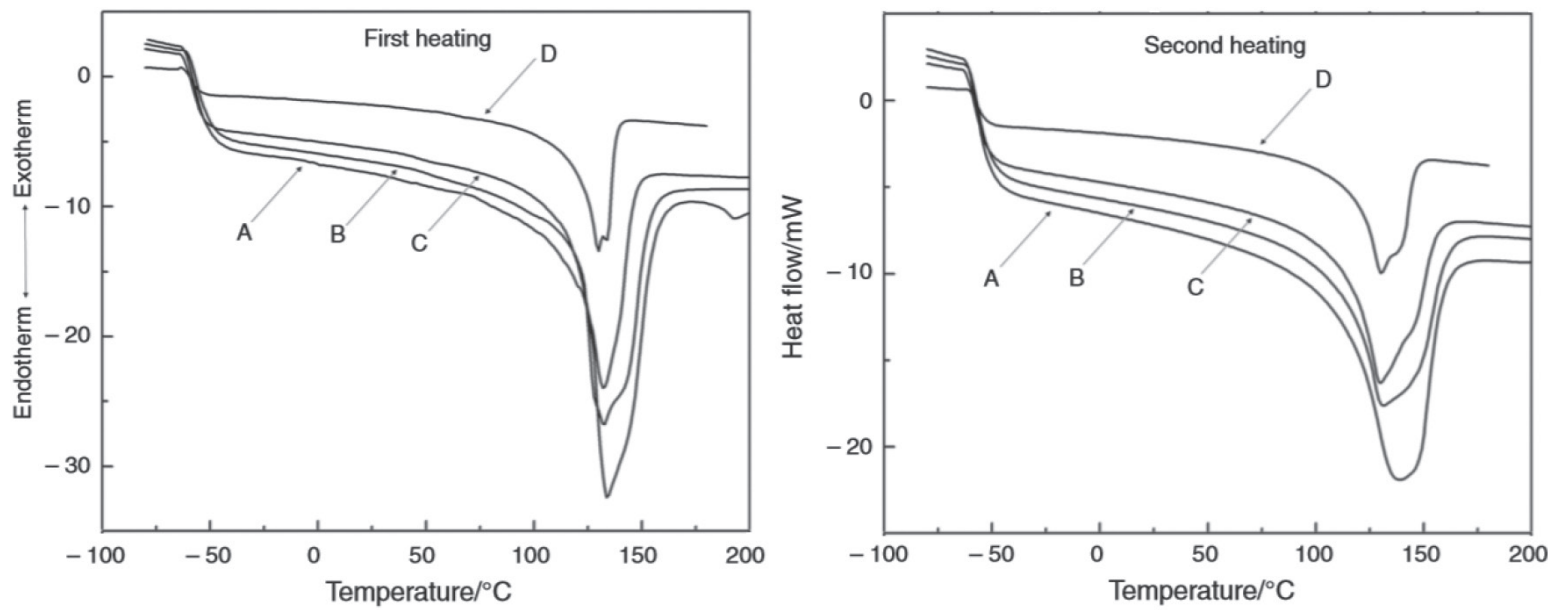

Figure 8. Differential scanning calorimetry heating curves of HDPE geomembrane samples under nitrogen gas purge ${ }^{84}$

Four HDPE geomembranes with $1.5 \mathrm{~mm}$ of thickness were immersed in a brine solution $(\mathrm{pH}=8.7)$ at $40,65,75$, and $85^{\circ} \mathrm{C}$ for 4 years and evaluated by Rowe and Shoaib. ${ }^{79}$ The half-life was less than 4 years of exposition at temperatures above $40{ }^{\circ} \mathrm{C}$ for the whole samples. Otherwise, the estimated lifetime using the stress cracking resistance test result values for one of the samples was more than 20 years at temperatures below $75^{\circ} \mathrm{C}$.

Coelho and Lavoie ${ }^{80}$ evaluated the behavior of two samples of HDPE geomembranes $(0.8 \mathrm{~mm}$ and $2.0 \mathrm{~mm}$ of thickness $)$ submitted to accelerated aging of up to 15,000 hours. The results of the tests performed on an accelerated aging chamber showed average losses in tensile elongation at break at around 20\% after 5,000 test hours, and less significant mean losses after 15,000 test hours, ranging from $11 \%$ for the geomembrane of $0.8 \mathrm{~mm}$ and $3 \%$ for the $2.0 \mathrm{~mm}$ sample. Therefore, it was observed that even after the accelerated weather exposure equivalent to 15 years, the product still retains more than $50 \%$ of its tensile elongation property and it is still suitable for its intended application. However, there is a tendency to reduce the mechanical properties after 15,000 hours of exposure to aging and it is, therefore, necessary to evaluate the material for longer periods.

Rowe and Shoaib ${ }^{81}$ investigated the heat-affected zone around the weld, the weld and the welded zone of an HDPE geomembrane (1.5 mm thick), utilizing dual wedge welding equipment with the samples immersed in synthetic leachate at different temperatures (40, 65,75 , and $85^{\circ} \mathrm{C}$ ). As a result, failures did not occur in the weld, but the slowest depletion of the antioxidants occurred in the weld, and the fastest depletion of the antioxidants occurred in the adjacent zone of the weld.

There is a lack of information on textured HDPE geomembranes in the literature. To the best of our knowledge, there is only one study carried out by Benson et al. ${ }^{82}$ who studied the behavior of LLDPE geomembrane seams. For this reason, Morsy and Rowe ${ }^{83}$ studied the textured HDPE geomembrane, $1.5 \mathrm{~mm}$ of total thickness and $0.43 \mathrm{~mm}$ of asperity thickness, and a smooth $1.5 \mathrm{~mm}$ thick HDPE geomembrane as a reference. Both samples were immersed at 75 and $85{ }^{\circ} \mathrm{C}$ in synthetic leachate. The results showed $15 \%$ less antioxidant depletion time than a smooth sample.

Tian et al. ${ }^{37}$ compared the depletion of antioxidants of a $2.0 \mathrm{~mm}$ thick high-density polyethylene geomembrane immersed in radioactive leachate and nonradioactive leachate, both synthetic, at $25,50,70$, and $90{ }^{\circ} \mathrm{C}$. The results showed that after 12 months of immersion at $90{ }^{\circ} \mathrm{C}$, the antioxidant depletion of the sample for both leachate samples was complete. The results of the flow index, after 15 months of exposure, decreased in values, demonstrating the occurrence of crosslinking. Finally, they concluded that the total service life of the sample after immersion in radioactive synthetic leachate was estimated at 1975 years.

Using laboratory blowing equipment and a $2.0 \mathrm{~mm}$ thick HDPE geomembrane, Tian et ll $^{78}$ created films with thicknesses of 0.04 , 0.1 , and $0.2 \mathrm{~mm}$, pulverizing sections mechanically and extruding the polymer. The samples were exposed to $\alpha$ and $\beta$ radiation and authors concluded that no important changes occurred in antioxidant depletion after the exposure and the estimative of the samples' service life was 1000 years.

Zhang et al..$^{51}$ tested an immersed HDPE geomembrane $(1.5 \mathrm{~mm}$ thick) in a very low $\mathrm{pH}$ solution $(\mathrm{pH}=0.5)$ at 85,75 , and $65^{\circ} \mathrm{C}$ for approximately 1.6 years. The authors concluded that there is no evidence of polymer degradation up to 19 months of exposure. The estimate of oxidant depletion time for $50{ }^{\circ} \mathrm{C}$ was 11 years, but for $520{ }^{\circ} \mathrm{C}$ it was 250 years, both for the standard tests.

Valentin et al. ${ }^{84}$ used thermal analysis to analyze HDPE geomembranes manufactured in Brazil by different suppliers. They tested four geomembranes with nominal thicknesses of $2.0 \mathrm{~mm}$ (A and B), $1.5 \mathrm{~mm}$ (C) and $0.8 \mathrm{~mm}$ (D). The samples presented different behaviors in the thermogravimetric analysis. Figures 8 and 9 present, respectively, the differential scanning calorimetry curves for heating and cooling at $20{ }^{\circ} \mathrm{C} \mathrm{min}-1$ of rate. In this study, several rates were used. The samples had overlapping reactions in the melting point, which was about $133{ }^{\circ} \mathrm{C}$. The melting point in the second heating widened compared to the first heating. The exothermic reaction can

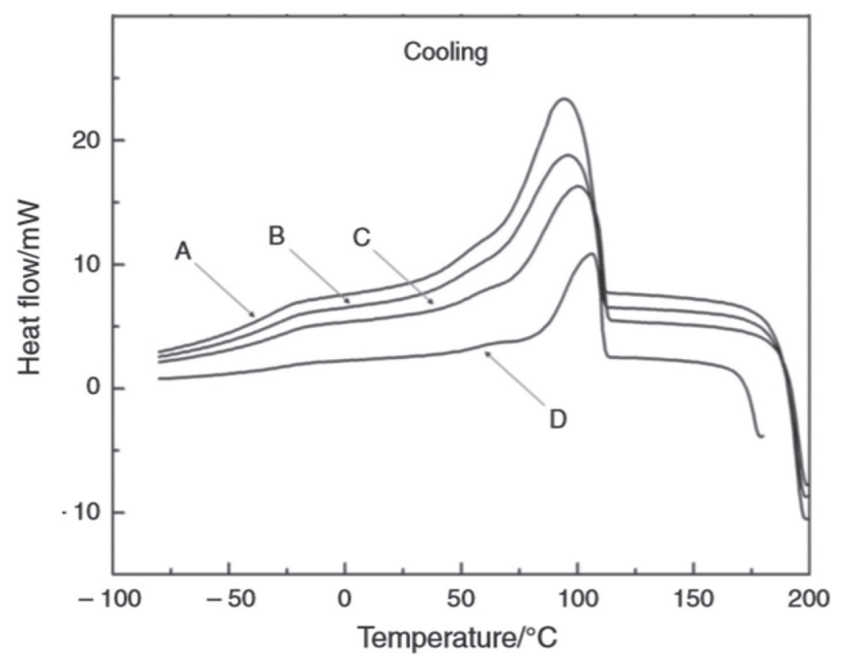

Figure 9. Differential scanning calorimetry cooling curve of HDPE geomembrane samples under nitrogen gas purge ${ }^{84}$ 
be observed on the cooling curve (at $115{ }^{\circ} \mathrm{C}$ ), showing polymer recrystallization. For the DMA tests, the authors concluded that there were no significant changes among the curves' behavior.

A long study over 17 years old with HDPE geomembranes immersed in air, water, and leachate at 85,70 and $55^{\circ} \mathrm{C}$ was conducted by Ewais et al. ${ }^{28}$ According to the authors, the oxidative degradation was clear by the loss in tensile properties, even loss in stress cracking resistance, especially for the sample immersed in water and leachate at $70{ }^{\circ} \mathrm{C}$. Finally, the service life was estimated at about 13 years for leachate at $60{ }^{\circ} \mathrm{C}$ and 660 years at $20^{\circ} \mathrm{C}$.

Abdelaal and Rowe ${ }^{85}$ studied a 3-year-old HDPE geomembrane without HALS (hindered amine stabilizer) immersed in solutions with chlorinated water at various concentrations at different temperatures. According to the authors, the depletion in the antioxidants and the stress cracking resistance were faster compared to other solutions, such as synthetic leachate and tap water. In general, the results showed the capacity of the chlorinated water at high temperatures in polymer degradation.

Abdelaal et al. ${ }^{29}$ conducted oxidative induction time tests, stress cracking tests, tensile tests and melt flow index tests to evaluate the behavior of an HDPE geomembrane with HALS under free chlorinated solutions in different conditions of temperature for about 70 months. Considering the increase in the solution concentration, the authors noted that fast degradation occurred. The estimated time to reach the service life of the product for free chlorinated water $(0.5 \mathrm{ppm})$ at $85^{\circ} \mathrm{C}$ was 5 years.

\section{Field studies of HDPE geomembrane durability}

Outdoor weathering exposure was conducted by Qureshi et al. ${ }^{86}$ at Dhahran, Saudi Arabia using $3.0 \mathrm{~mm}$ thick linear low-density polyethylene (LLDPE). The sample was produced without an ultraviolet stabilizer. The location of the exposure has similar solar radiation to solar radiation in Arizona, USA (hot and humid). In three months of exposure, the sample showed a decrease of $50 \%$ in tensile strength and elongation at break. According to the authors, photochemical degradation was verified due to chain scission and cross-linking reactions.

The investigation of $1.0 \mathrm{~mm}$ thick HDPE geomembrane seam failures was proceeded by Calabria and Peggs ${ }^{87}$ in the closure of an eastern Pennsylvania landfill in the US. The authors divided the area into two sections to facilitate the investigation. Fusion and extrusion seams were made in this construction site. In conclusion, the landfill gas did not influence these failures and the cause of these failures was dirt within the seams during the installation.

Koerner et al. ${ }^{8}$ evaluated the effects of waves in an exhumed HDPE geomembrane of $1.5 \mathrm{~mm}$. The material was installed for 8 years in a municipal landfill. According to the authors, they found three different types of waves, "prayer" wave, "s" wave and "mushroom" wave in the field. The laboratory investigation was conducted on flat, as well as waved geomembrane test specimens in order to evaluate the tensile strength properties, and stress cracking properties. As a result of the tests conducted, the tensile strength appears not to be significantly compromised. The geomembrane used at this site is a very high-quality stress cracking resistant material with failure times in excess of 1823 hours. There appears to be a decrease in stress cracking resistance of waved versus non-waved geomembrane test specimens. There is a tendency for the stress cracking resistance to decrease, but it is still well above current specification values for this particular property.

Koerner and Koerner ${ }^{52}$ monitored the in-situ temperature of HDPE geomembranes used in a solid waste landfill liner and cover. The sensor called "dry cell" measured a non-liquid area, and the sensor called "wet cell" measured the high moisture area. Over 10.5 years of monitoring the "dry cell" and 3.7 years of monitoring the "wet cell", the temperature for the "dry cell" was, on average, $20^{\circ} \mathrm{C}$, and the temperature for the "wet cell" temperature started at $25^{\circ} \mathrm{C}$ and increased to $41-46{ }^{\circ} \mathrm{C}$.

Lodi et al. ${ }^{15}$ exposed HDPE geomembranes to weathering ( $0.8 \mathrm{~mm}$ and $2.5 \mathrm{~mm}$ thick) for $6,12,18$, and 30 months. The location of this research was in the southwest of Brazil $\left(20^{\circ} 22^{\prime} \mathrm{S}\right.$ and $51^{\circ} 22^{\prime} \mathrm{W}$ ). They verified the physical, mechanical and thermal properties of these samples. The melt flow index results indicated the beginning of the degradation. The $0.8 \mathrm{~mm}$ sample showed an increase in melt flow index results, probably caused by chain scissioning.

Richgels ${ }^{88}$ evaluated field ultraviolet exposure and its effects. Field measurements of total and UV solar irradiation and temperature were available near Phoenix, Arizona and Miami, Florida in the US, from the Atlas Weathering Services Group. Using Arrhenius modeling, a half-life of exposed high-density polyethylene geomembrane was estimated in Miami in approximately 250 years. The projected line from the assumed stage of polymer degradation field data shows estimated half-life at approximately 220 years in Arizona. According to the author, after the sun has passed its daily peak irradiation time, the thermal oxidation continues to occur in the geomembrane. Thermal energy will continue the polymer oxidation process of polyolefin resins.

Reis et al. ${ }^{89}$ evaluated five high-density geomembranes (HDPE), $2.0 \mathrm{~mm}$ thick, exposed to climate conditions over 12 years in 8 different regions of Portugal with different ultraviolet indexes. The samples, covered with geotextile and uncovered, were evaluated regarding their influence of protection for geomembranes. Many properties were evaluated, such as density, melt flow index, tensile strength, carbon black content, and oxidative induction time (OIT). The results show that the properties of the geomembranes exposed to climatic conditions present some deterioration, especially regarding the OIT and density. As for the geomembranes exposed in locations with different UV indexes, it suggests that an increase of this index impacts the tensile properties and OIT. Finally, it was found which covered and exposed samples presented similar results.

\section{Laboratory studies of exhumed HDPE geomembrane durability}

The municipal waste landfill double liner system was exhumed by Eith and Koerner ${ }^{5}$ in the Mid-Atlantic Region of the US. Two layers of primary and secondary HDPE geomembranes of $1.5 \mathrm{~mm}$ thick were installed and they were exposed to leachate, methane, and stresses for 8 years. Physical, mechanical and endurance properties were evaluated, and no degradation was detected.

Hsuan $^{49,90}$ carried out NCTL tests in 18 commercially new HDPE geomembranes and seven field HDPE geomembranes. The test results reveal a wide range of transition times $\left(T_{t}\right)$. It can be observed that the transition time is key to comparing the behavior of the different samples tested. High transition time means good stress cracking resistance. The highest transition time value of the seven field geomembranes was 97 hours and the second highest value was 55 hours. Regarding the new geomembranes tested, a half of those presented transition times less than 100 hours.

Benson et al. ${ }^{82}$ exhumed different types of geosynthetics from a liner cover of a landfill in Wisconsin, the US, including a textured low linear density polyethylene (LLDPE) geomembrane, $1.0 \mathrm{~mm}$ thick. The geosynthetics had about 5 years of service. Both the melt flow index and the oxidative induction time did not show any changes compared to the tests under manufacturing quality control (MQC) at construction time. The tensile yield strength decreased 1.2 times 
compared to the MQC results, but it is not possible to affirm that there was chemical degradation due to this.

Seven-year-old exhumed fluorinated HDPE geomembranes from the Canadian Arctic were evaluated by Rowe et al. ${ }^{91}$ Geomembranes with thicknesses of $1.0 \mathrm{~mm}, 1.5 \mathrm{~mm}$ and $2.0 \mathrm{~mm}$ were exhumed by a hydrocarbon spill backfill liner system. Melt flow index, oxidative induction time, crystallinity and tensile strength were used to study these samples. There were no changes detected in the melt flow index, crystallinity and tensile strength. According to Arrhenius modeling, the antioxidant depletion of a $1.5 \mathrm{~mm}$ thick sample was about 140 years for standard oxidative induction time and over 200 years for high-pressure oxidative induction time.

High-density geomembranes with $1.5 \mathrm{~mm}$ of thickness were exhumed by Safari et al..$^{92,93}$ after 25 years of service from hazardous waste landfill liners (bottom and cover liners) at London Ontario, Canada. Using the Arrhenius modeling and oxidative induction time method, the authors concluded that the total time remaining for the antioxidant depletion is, on average, 60 years. Table 3 shows OIT results and the ratio of HP-OIT/ST-OIT for exhumed samples.

The standard OIT test results were considerably lower than those of typical modern-day geomembranes. The high-pressure OIT test results of the cover geomembranes were also lower than typical high pressure OIT values of the virgin geomembranes of today. The ratio of HP-OIT/ST-OIT was similar for four of the five locations. ${ }^{92}$

The behavior of a $1.5 \mathrm{~mm}$ thick exhumed HDPE geomembrane, used as a liner in the San Isidro reservoir located on the Canary Islands, Spain, was evaluated by Noval et al. ${ }^{94}$ The authors used samples from the north and south slopes with 138, 162 and 174 months of age. The scanning electron microscopy results can be seen in Figure 10. After 138 months, the north slope sample showed the presence of grooves by manipulation (Figure 10a). After 162 months of exposition, the north slope sample presented cracks (Figure 10c). Figure $10 \mathrm{~b}$ and $10 \mathrm{~d}$ present the south slope sample after 174 months. A crack can be seen in Figure 10d.

Tensile strength properties were evaluated over 20 years of exposition, the variation in tensile properties is shown in Figure 11. The values had a huge variation and the elongation at break decreased less than $50 \%$ of the original value in approximately 8 years. The depletion of antioxidants was estimated at 47 years for the northern slope sample and 58 years for the southern slope sample. Finally, the authors concluded that the geomembrane performed well as a liner. ${ }^{94}$

Rowe and Ewais ${ }^{16}$ evaluated two exhumed samples of $1.5 \mathrm{~mm}$ high-density polyethylene geomembranes in different places. They proceeded the exhumation of a 16-year-old geomembrane in a mining facility in Argentina, and a 6-year-old geomembrane in the
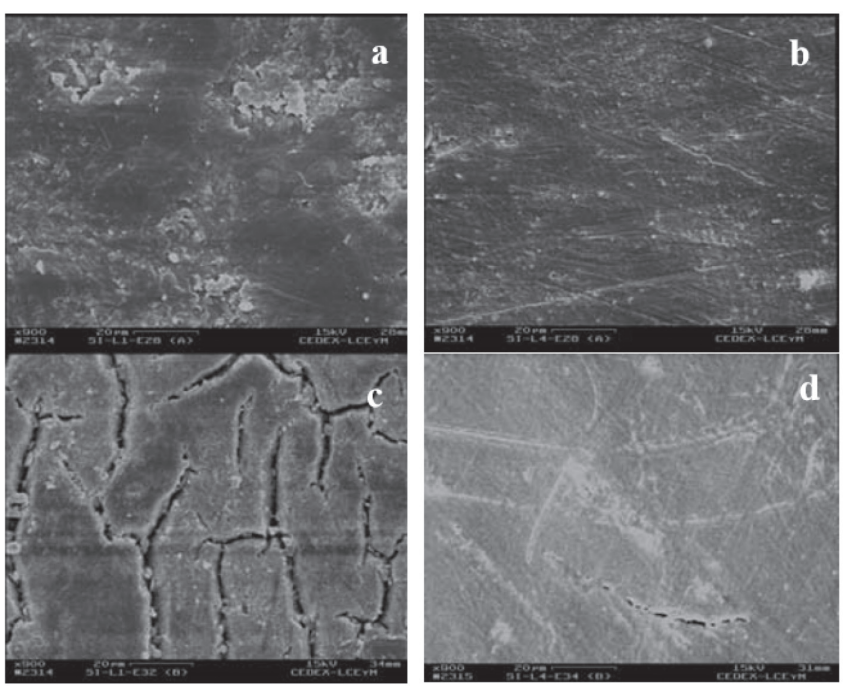

Figure 10. Scanning electron microscopy of the exhumed HDPE samples ${ }^{94}$

research site of Queen's University, Canada. The results showed the time nominal failure was reached in stress cracking resistance for the mine facility sample. For the Canadian sample, the depletion of antioxidants was faster in the slope than the bottom.

Santos and Gardoni ${ }^{95,96}$ studied a $1.5 \mathrm{~mm}$ thick HDPE geomembrane, used in a Brazilian tailing dam from 2006 to 2010. The tests were run on the virgin sample, laboratory aged sample and sample directly exhumed from the dam, thus comparing the durability and concluding the degree of aging and loss of durability. Chemical and mechanical durability tests, thermogravimetric tests, scanning electron microscopy (SEM) analysis, tensile tests on virgin and aged geomembranes were performed. The aged equipment was designed to reproduce field conditions such as the effects of solar radiation on the ultraviolet and infrared spectrum, as well as to simulate samples of immersion in the contaminated fluid for the study of aging on laboratory exposure of the samples to ultraviolet radiation, infrared radiation $\left(40{ }^{\circ} \mathrm{C}\right)$ and immersing the samples in fluid cyanide. Durability tests were performed on the geomembranes immersed in the fluid barrier and the temperature and UV exposure conditions were simulated. The SEM results showed that the exhumed samples show degradation, with some cracking process underway, cavities and the surface with some degree of roughness were also observed. According to the authors, the exhumed sample presented a significant degree of degradation on its surface. The samples submitted to thermogravimetric analysis showed values of mass loss compatible

Table 3. OIT results and the ratio of HP-OIT/ST-OIT for exhumed geomembranes ${ }^{92}$

\begin{tabular}{ccccc}
\hline Geomembrane & Age (year) & ST-OIT (min) & HP-OIT (min) & HP-OIT/ST-OIT \\
\hline Cover Cell 1 & 25 & $15 \pm 1.6$ & $114 \pm 10$ & 7.6 \\
Cover Cell 2 & 24 & $24 \pm 1.5$ & $155 \pm 7$ & 6.5 \\
Cover Cell 3 & 23 & $27 \pm 4.6$ & $163 \pm 15$ & $193 \pm 5$ \\
Cover Cell 4-1 & 22 & $25 \pm 1.9$ & $121 \pm 13$ & 7.5 \\
Cover Cell 4-2 & 22 & $9 \pm 1.2$ & $68 \pm 3.4$ & 14 \\
Bottom Liner Cell 3-1 & 23 & $7 \pm 0.8$ & $64 \pm 3.7$ & 9.2 \\
Bottom Liner Cell 3-2 & 23 & $8 \pm 1$ & $143 \pm 26$ & 8.0 \\
Bottom Liner Cell 4-1 & 22 & $53 \pm 1$ & $162 \pm 16$ & 2.7 \\
Bottom Liner Cell 4-2 & 22 & $52 \pm 0.5$ & $188 \pm 21$ & 3.1 \\
Sidewall Cell 3-1 & 23 & $62 \pm 0.7$ & $197 \pm 9.7$ & 3.0 \\
Sidewall Cell 3-2 & 23 & $60 \pm 0.9$ & 3.3 \\
\hline
\end{tabular}




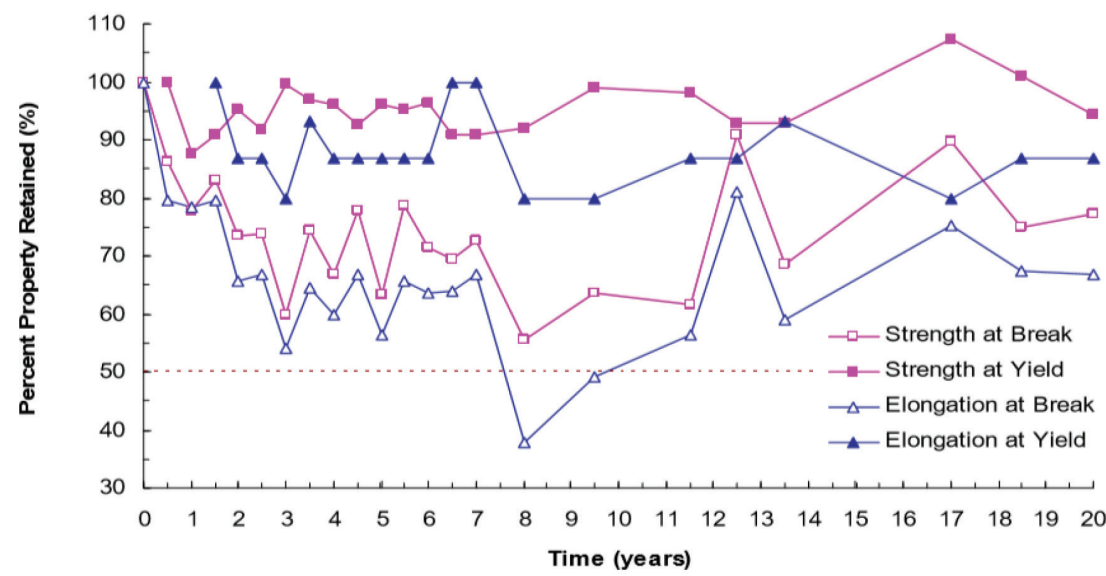

Figure 11. The variation in tensile properties over 20 years $^{94}$

with the one found in the literature and other research. The samples showed no significant loss of mass when comparing virgin, exhumed and aged samples.

\section{HDPE GEOMEMBRANE WITH NANOPARTICLES}

To increase the thermal, mechanical and barrier properties of high-density polyethylene geomembranes, the incorporation of nanocomposites in the polymer blend is used as a new method. For instance, nanoclays are utilized with organic groups. The nanoparticles need to be properly dispersed in the polymer matrix. Besides that, polar compatibilizing agents are included in the formulation to refine the dispersion. However, the ideal conditions to improve the nanoparticle dispersion in the polymer matrix is still a challenge. ${ }^{97}$

Cussier et al. ${ }^{98}$ developed an HDPE geomembrane containing zero-valent iron $\left(\mathrm{Fe}^{0}\right)$ nanoparticles to apply as a reactive barrier. The nanoparticles of $\mathrm{Fe}^{0}$ were produced by an anaerobic chamber with sodium borohydride and ferric chloride. The polymer was mixed with the nanoparticles using a batch mixer. The partitioning coefficient and diffusion coefficient were calculated from breakthrough curves and the calculation estimates that only of $2.0 \%-3.0 \%$ of the $\mathrm{Fe}^{0}$ nanoparticles reacted before the breakthrough of carbon tetrachloride.

The diffusion evaluation of multiwall carbon nanotubes through a $0.5 \mathrm{~mm}$ thick high-density polyethylene geomembrane was presented by Taghizadeh-Saheli et al. ${ }^{99}$ The carbon nanotube concentration was measured by a TOC analyser. The results have shown no significant partitioning of multiwall carbon nanotubes from source to geomembrane or diffusion throughout the 1 month of test. According to the authors, the production of carbon nanotubes is increasing because of the increasing demand and these kinds of nanoparticles will be used in landfill barrier systems.

The reduction of thermal expansion in high-density polyethylene geomembranes using nanoclay particles was studied by Dolez et al. ${ }^{100}$ The authors prepared several ratios of nanoclay particles from $0.5 \%$ to $50 \%$ dispersed in an HDPE geomembrane and used a series of olefinbased polar compatibilizing agents with $5 \%$ and $10 \%$. They used a dynamic mechanical analyser (DMA) to evaluate the coefficient of linear thermal expansion and the transmission electron microscopy (TEM) to evaluate the nanoclay particles' degree exfoliation. The reduction in thermal expansion in comparison with a condition without a compatibilizing agent was noted only for one of the agents used in this study.

Dolez et al. ${ }^{97}$ analyzed HDPE geomembranes with nanocomposites through mechanical properties. The nanocomposite samples were prepared by a twin-screw extruder utilizing LLDPE (low linear density polyethylene), HDPE (high-density polyethylene), various percentages of an organic-modified nanoclay, and four compatibilizing agents. The results indicate better compatibility of the nanoclay with an LLDPE masterbatch than the HDPE one. The decrease in tensile properties was observed for nanoclay concentrations over 5\%, probably due to imperfect bonding between the nanoclay and polymer matrix.

Saheli et al. ${ }^{101}$ studied the diffusion of multiwall carbon nanotubes (MWCNTs) dispersed in an aqueous media through an HDPE geomembrane. The permeation coefficient was approximated in $5.1 \times 10^{-15} \mathrm{~m}^{2} \mathrm{~s}^{-1}$ by laboratory tests and six different blend combinations. The low permeation coefficient value shows an HDPE geomembrane's effective diffuse barrier using nanotubes.

\section{GOOD PRACTICE OF HDPE GEOMEMBRANE INSTALLATION}

In addition to excellent resin, a suitable additive package, good industrial processability, good manufacturing quality control, satisfactory material specification for applications and good installation practice must be specified and supervised in the field by the designer. The implications of bad installation procedures can lead to a short-term service life of high-density polyethylene geomembranes. In Brazil, there is a technical standard ${ }^{102}$ and a technical recommendation ${ }^{103}$ concerning geomembrane installation practice. Both documents include the importance of the type of application to protect the product and good workmanship such as proper welding equipment, field seam testing, destructive seam testing, and avoiding damage and stress concentration in the product.

\section{CONCLUSIONS}

Different types of conditions and exposures drive the behavior of HDPE geomembranes, including field temperature conditions and contact with different types of chemical substances. Investigations of both exhumed and laboratory samples can indicate different behaviors and responses concerning HDPE geomembrane durability.

Accelerated HDPE geomembrane laboratory tests, simulating field boundary conditions are mainly for future use of this geosynthetic. In addition, thermal analysis has shown the importance in gaining more knowledge about the behavior of exposed geomembranes.

\section{REFERENCES}

1. Rollin, A. R.; Rigo, J. M.; Geomembranes - Identification and Performance Testing, $1^{\text {st }}$ ed., Chapman and Hall: London, 1991. 
2. Rowe, R. K. In Geotechnical and Geoenvironmental Engineering Handbook; Rowe, R. K., ed.; Kluwer Academic: Norwell, 2001, cap. 25.

3. Lopes, M. P.; Lopes, M. L.; A Durabilidade dos Geossintéticos, $1^{\mathrm{a}}$ ed., FEUP Edições: Porto, 2010.

4. Palmeira, E. M.; Geossintéticos em Geotecnia e Meio Ambiente, $1^{\mathrm{a}}$ ed., Oficina de Textos: São Paulo, 2018.

5. Eith, A. W.; Koerner, G. R.; Geotextiles and Geomembranes 1997, 15, 277.

6. Koerner, R. M.; Designing with Geosynthetics, $5^{\text {th }}$ ed., Prentice Hall: New Jersey, 2005.

7. Scheirs, J.; A guide to Polymeric Geomembranes: a practical approach, $1^{\text {st }}$ ed., Wiley: London, 2009.

8. Koerner, G. R.; Eith, A. W.; Tanese, M.; Geotextiles and Geomembranes 1999, 17, 247.

9. Vertematti, J. C.; Manual Brasileiro de Geossintéticos, $2^{\mathrm{a}}$ ed., Edgard Blücher: São Paulo, 2015.

10. Rowe, R. K.; Sangam, H. P.; Geotextiles and Geomembranes 2002, 20, 77.

11. Kay, D.; Blond, E.; Mlynarek, J.; $57^{\text {th }}$ Canadian Geotechnical Conference, Quebec, Canada, 2004.

12. Hsuan, Y. G.; Koerner, R. M.; Geosynth. Int. 1995, 2, 831.

13. Lodi, P. C.; Bueno, B. S.; The Electronic Journal of Geotechnical Engineering 2012, 17, 3339.

14. Ewais, A. M. R.; Rowe, R. K.; Scheirs, J.; Geotextiles and Geomembranes 2014, 42, 111.

15. Lodi, P. C.; Bueno, B. S.; Vilar, O. M.; Mater. Res. 2013, 16, 1331.

16. Rowe, R. K.; Ewais, A. M. R.; Can. Geotech. J. 2015, 52, 326.

17. Perkins, S. W. In Geosynthetics in Civil Engineering; Sarsby, R. W., ed.; Woodhead Published Limited: Cambridge, 2007, cap. 2.

18. Hsuan, Y. G.; Schroeder, H. F.; Rowe, K.; Muller, W.; Greenwood, J.; Cazzuffi, D.; Koerner, R. M.; Eurogeo 4, the $4^{\text {th }}$ European Geosynthetics Conference, Edinburgh, United Kingdom, 2008.

19. Peggs, I. D.; Kanninen, M. F.; Geosynth. Int. 1995, 2, 327.

20. Giroud, J. P.; Geosynth. Int. 1994, 1, 93.

21. Greenwood, J. H.; Schroeder, H. F.; Voskamp, W.; Durability of Geosynthetics, $1^{\text {st }}$ ed., Curnet: Gouda, 2012.

22. Kelen, T.; Polymer Degradation, $1^{\text {st }}$ ed., Van Nostrand Reinhold Co.: New York, 1983.

23. Grassie, N.; Scott, G.; Polymer Degradation and Stabilization, $1^{\text {st }}$ ed., Cambridge University Press: New York, 1985.

24. Chirinos-Padrón, A. J.; Allen, N. S. In Handbook of Polymer Degradation; Hamid, A. H.; Amin, M. B.; Maadhah, A. G., eds.; Marcel Dekker: New York, 1992, cap. 8.

25. Fay, J. J.; King, R. E. In: Geosynthetic Resins, Formulations and Manufacturing; Hsuan, Y. G.; Koerner, R. M., eds.; Industrial Fabric Assn. Intl.: St. Paul, 1994, cap. 4.

26. Tisinger, L. G.; Giroud, J. P.; Geotechnical Fabrics Report 1993, 11, 4.

27. Tian, K.; Benson, C. H.; Yang, Y.; Tinjum, J. M.; Geotextiles and Geomembranes 2018, 46, 426.

28. Ewais, A. M. R.; Rowe, R. K.; Rimal, S.; Sangam, H. P.; Geosynth. Int. 2018, 25, 525.

29. Abdelaal, F. B.; Morsy, M. S.; Rowe, R. K.; Geotextiles and Geomembranes (2019), doi: 10.1016/j.geotexmem.2019.103497.

30. Rowe, R. K.; Abdelaal, F. B.; Brachman, R. W. I.; Geosynth. Int. 2013, 20,73 .

31. Van Santvoort, G.; Geotextiles and geomembranes in civil engineering, $1^{\text {st }}$ ed., A. A. Balkema: Rotterdam, 1994.

32. Lodi, P. C.; Bueno, B. S.; Zornberg, J. G.; Revista Minerva-Pesquisa e Tecnologia 2008, 4, 201.

33. Islam, M. Z.; Gross, B. A.; Rowe, R. K.; Geo-Frontiers 2011: Advances in Geotechnical Engineering, Dallas, USA, 2011.

34. Sharma, H. D.; Lewis, S. P.; Waste containment system, waste stabilization and landfills: design and evaluation, $1^{\text {st }}$ ed., Wiley: New York, 1994.
35. Take, W. A.; Rowe, R. K.; Brachman, R. W. I.; Arnepalli, D. N.; Geosynth. Int. 2015, 22, 93.

36. Suits, L. D.; Hsuan, Y. G.; Geotextiles and Geomembranes 2003, 21 , 111.

37. Tian, K.; Benson, C. H.; Tinjum, J. M.; Edil, T. B.; Journal of Geotechnical Geoenvironmental Engineering 2017, 143, 04017011-1.

38. Koerner, G. R.; Hsuan, Y. G.; Koerner, R. M. In Geosynthetics in Civil Engineering; Sarsby, R. W., ed.; Woodhead Published: Cambridge, 2007, cap. 3 .

39. Abdelaal, F. B.; Rowe, R. K.; Hsuan, Y. G.; Awad, R.; Geosynth. Int. 2015, 22, 207.

40. Rowe, R. K.; Can. Geotech. J. 2012, 49, 141.

41. Telles, R. W.; Lubowitz, H. R.; Unger, S. L; Assessment of Environmental Stress Corrosion of Polyethylene Liners in Landfills and Impoundments, $1^{\text {st }}$ ed., U.S. EPA: Cincinnati, 1984.

42. Peggs, I. D.; Carlson, D. S. In Durability and Aging of Geosynthetics; Koerner, R. M., ed.; Elsevier: London, 1989, cap. 3.

43. Halse, Y. H.; Koerner, R. M.; Lord Jr., A. E. In Durability and Aging of Geosynthetics; Koerner, R. M., ed.; Elsevier: London, 1989, cap. 7.

44. Halse, Y. H.; Lord Jr., A. E.; Koerner, R. M. In Geosynthetic Testing for Waste Containment Applications, Koerner, R. M., ed., ASTM International: West Conshohocken, 1990, cap. 7.

45. Dix, J. S.; Burkinshaw, J. S.; Geotextiles and Geomembranes 1991, 10, 621.

46. Lavoie, F. L.; Bueno, B. S.; Lodi, P. C.; Dyna 2014, 183, 215.

47. Muñoz Gómez, M.; $3^{\text {rd }}$ Pan American conference on geosynthetics, Miami, USA, 2016.

48. Peggs, I. D.; Kanninen, M. F.; Geosynth. Int. 1995, 2, 327.

49. Hsuan, Y. G.; Geotextiles and Geomembranes 2000, 18, 1.

50. Rowe, R. K.; Geotechnique 2005, 55, 631.

51. Zhang, L.; Bouazza, A.; Rowe, R. K.; Scheirs, J.; Geosynth. Int. 2018 , $25,118$.

52. Koerner, G. R.; Koerner, R. M.; Geotextiles and Geomembranes 2006 , 24,72 .

53. Koerner, R. M.; Lord, A. E.; Hsuan, Y. H.; Geotextiles and Geomembranes 1992, 11, 151.

54. Rimal, S.; Rowe, R. K.; Geosynth. Int. 2009, 16, 482.

55. Hsuan, Y. G.; Koerner, R. M.; J. Geotech. Geoenviron. Eng. 1998, 124 , 532.

56. Gulec, S. B.; Edil, T. B.; Benson, C. H.; Geosynth. Int. 2004, 11, 60.

57. Jessberger, H. L.; Heibrock, G. In Advanced Landfill Liner Systems; August, H.; Holzlohner, U.; Meggyes, T., eds.; Thomas Telford: London, 1997, pp. 101-109, cap. 1.

58. Mitchell, D. H.; Geotextiles and Geomembranes 1985, 2, 111

59. Schoenbeck, M. A.; Geotextiles and Geomembranes 1990, 9, 337.

60. Dix, J. S.; Burkinshaw, J. R.; Geotextiles and Geomembranes 1991, 10, 621.

61. Aminabhavi, T. M.; Naik, H. G.; Geotextiles and Geomembranes 1998, $16,333$.

62. Merry, S. M.; Bray, J. D.; Yoshitomi, S.; Geosynth. Int. 2005, 12, 156.

63. Islam, M. Z.; Rowe, R. K.; $60^{\text {th }}$ Canadian Geotechnical Conference and the $8^{\text {th }}$ Joint CGS/IAH-CNC Groundwater Conference, Ottawa, Canada, 2007.

64. Rowe, R. K.; Islam, M. Z.; Hsuan, Y. G.; Geosynth. Int. 2008, 15, 136.

65. Koerner, R. M.; Hsuan, Y. G.; Koerner, G. R.; $1^{\text {st }}$ Pan American conference on geosynthetics, Cancun, Mexico, 2008.

66. Rowe, R. K.; Rimal, S.; Sangam, H.; Geotextiles and Geomembranes 2009, 27, 137.

67. Rowe, R. K.; Hoor, A.; Geosynth. Int. 2009, 16, 71.

68. Lavoie, F. L.; Bueno, B. S.; Lodi, P. C.; The Electronic Journal of Geotechnical Engineering 2012, 17, 3097.

69. Abdelaal, F. B.; Rowe, R. K.; Smith, M.; Brachman, R. W. I.; Thiel, R.; $2^{\text {nd }}$ Pan American conference on geosynthetics, Lima, Peru, 2012. 
70. Lodi, P. C.; Bueno, B. S.; Hamada, J.; de Oliveira, E. L.; da Silva, G. H. R.; The Electronic Journal of Geotechnical Engineering 2013, 18, 1227.

71. Lavoie, F. L.; Bueno, B. S.; Lodi, P. C.; Polimeros 2013, 23, 690.

72. Buaszczyk, G.; Dissertação de Mestrado, Universidade Federal de São Carlos, Brasil, 2013.

73. Abdelaal, F. B.; Rowe, R. K.; $10^{\text {th }}$ International Conference on Geosynthetics, Berlin, Germany, 2014.

74. Abdelaal, F. B.; Rowe, R. K.; Geotextiles and Geomembranes 2014, 42, 284.

75. Abdelaal, F. B.; Rowe, R. K.; Islam, M. Z.; Geotextiles and Geomembranes 2014, 42, 348.

76. Morsy, M. S.; Rowe, R. K.; $3^{\text {rd }}$ Pan American conference on geosynthetics, Miami, USA, 2016.

77. Ewais, A. M. R.; Rowe, R. K.; Brachman, R. W. I.; $3^{\text {rd }}$ Pan American conference on geosynthetics, Miami, USA, 2016.

78. Koerner, R. M.; Hsuan, Y. G.; Koerner, G. R.; Geosynth. Int. 2017, 24, 198.

79. Rowe, R. K.; Shoaib, M.; Geosynth. Int. 2017, 24, 508.

80. Leme, M. F.; Lavoie, F. L.; $14^{\circ}$ Congresso Brasileiro de Polímeros, Águas de Lindóia, Brasil, 2017.

81. Rowe, R. K.; Shoaib, M.; Can. Geotech. J. 2017, 54, 1623.

82. Benson, C. H.; Kucukkirca, I. E.; Scalia, J.; Geotextiles and Geomembranes 2010, 28, 536.

83. Morsy, M. S.; Rowe, R. K.; $19^{\text {th }}$ International Conference on Soil Mechanics and Geotechnical Engineering, Seoul, South Korea, 2017.

84. Valentin, C. A.; Silva, J. L.; Kobelnik, M.; Ribeiro, C. A.; Journal of Thermal Analysis and Calorimetry (2018), doi: 10.1007/s10973-0187690-0.

85. Abdelaal, F. B.; Rowe, R. K.; Geosynth. Int. 2019, 26, 354.

86. Qureshi, F. S.; Amin, M. B.; Maadha, A. G.; Hamid, S. H.; Polym.-Plast. Technol. Eng. 1989, 28, 649.

87. Calabria, C. R.; Peggs, I. D.; Geotextiles and Geomembranes 1997, 15, 419.
88. Richgels, C. M.; $3^{\text {rd }}$ Pan American conference on geosynthetics, Miami, USA, 2016

89. Reis, R. K.; Barroso, M.; Lopes, M. G.; Geotecnia 2017, 141, 41.

90. Hsuan, Y. G.; Koerner, R. M.; Lord Jr., A. E.; J. Geotech. Eng. 1993, 119,1840

91. Rowe, R. K.; Rimal, S.; Arnepalli, D. N.; Bathurst, R. J.; Geotextiles and Geomembranes 2010, 28, 100.

92. Safari, E.; Rowe, R. K.; Markle, J.; Pan Am CGS Geotechnical Conference, Toronto, Canada, 2011.

93. Adams, M. W.; Wagner, N.; Geotechnical Fabrics Report 2000, 18, 36.

94. Noval, A. M.; Blanco, M.; Castillo, F.; Leiro, A.; Mateo, B.; Zornberg, J. G.; Aguiar, E.; Torregrosa, J. B.; Redón, M.; $10^{\text {th }}$ International Conference on Geosynthetics, Berlin, Germany, 2014.

95. Santos, L. S.; Gardoni, M. G. A.; $3^{\text {rd }}$ Pan American conference on geosynthetics, Miami, USA, 2016.

96. Santos, L. S.; Dissertação de Mestrado, Universidade de Minas Gerais, Brasil, 2014.

97. Dolez, P. I.; Weltrowski, M.; David, E.; Geotechnical Frontiers, Orlando, USA, 2017.

98. Shimotori, T.; Cussier, E. L.; Arnold, W. A.; J. Environ. Sci. 2006, 132, 803.

99. Taghizadeh-Saheli, P.; Rowe, R. K.; Petersen, E. J.; O'Carroll, D. M.; 66 $6^{\text {th }}$ Canadian Geotechnical Conference, Montreal, Canada, 2013.

100. Dolez, P. I.; Ragoubi, N.; David, E.; Weltrowski, M.; Advanced Materials: TechConnect Briefs 2016, 1, 296.

101. Saheli, P. T.; Rowe, R. K.; Petersen, E. J.; O'Carrol, D. M.; Geosynthetics International (2017), doi:10.1680/jgein.16.00025.

102. Associação Brasileira de Normas Técnicas. ABNT NBR 16199:2013; Geomembranas termoplásticas - Instalação em obras geotécnicas e de saneamento Ambiental; Rio de Janeiro, 2013, p. 30.

103. Associação Brasileira de Geossintéticos, Recomendação IGS Brasil $004-$ 2016, Aplicação de Geossintéticos em Áreas de Disposição de Resíduos, São José dos Campos, 2016, p. 40. 